\title{
Analytical Method Development and Validation for Simultaneous Estimation of Doxofylline and Montelukast Sodium in Bulk and Pharmaceutical Dosage Form
}

\author{
S. Marakatham*, B. Divya, Meruva Sathish Kumar \\ Malla Reddy Institute of Pharmacy, Maisammaguda, Secunderabad.
}

\begin{abstract}
A rapid, precise and accurate reverse phase high performance liquid chromatographic method have been developed for the validated of DOXOFYLLINE AND MONTELUKAS SODIUM, in its original form as well as in pharmaceutical dosage form. Chromatography conditionswas carried out on a Phenomenex HYPERSIL ODS, RP$18,250 \times 4.6 \mathrm{~mm} I D$, column using a mixture of Ammonium acetate: Methanol (60:40) as the mobile phase at a flow rate of $1.0 \mathrm{ml} / \mathrm{min}$, the detection was carried out at $219 \mathrm{~nm}$. The retention time of the DOXOFYLLINE AND MONTE LUKAS SODIUM was 2.34, 4.81 \pm 0.02 min respectively. The method produce linearity responses in the range of 1.5$3.5 \mathrm{mg} / \mathrm{ml}$ of DOXOFYLLINE and 60-140mg/ml of MONTELUKAS SODIUM. The limit of detection of Montelukast \&amp; Doxofylline $0.021 \mu \mathrm{g} / \mathrm{ml} \&$ amp; area 2.61 and $1.54 \mu \mathrm{g} / \mathrm{ml} \&$ amp; area 104.45 respectively. The limit of quantitation of Montelukast was found to be $0.06 \mu \mathrm{g} / \mathrm{ml}$ \&amp; area 7.91 whereas for Doxofylline was $4.68 \mu \mathrm{g} / \mathrm{ml}$ \&amp; area 316.51. The percentage of recovery of Montelukast and Doxofylline was found to be $99.96 \%$ and $100.85 \%$ respectively. The method is useful for the quality and quality control of bulk and pharmaceutical formulations.
\end{abstract}

Keywords: DOXOFYLLINE, MONTELUKAST SODIUM, RP-HPLC, validation.

\section{INTRODUCTION}

Montelukast is a leukotriene receptor antagonist (LTRA) with iupac name 2-[1- (\{[(1R)-1- \{3-[(E)- 2(7- chloroquinolin-2- yl) ethenyl] phenyl $\}-3-[2-(2-$ hydroxypropan-2 yl) phenyl] propyl] sulfanyl $\}$ methyl) cyclopropyl]acetic. For the maintenance treatment ofasthma and to relieve symptoms of seasonal allergies. Ritonavir is a Antiretroviral drug 1,3-thiazol- 5-ylmethyl N-[(2S,3S,5S)-3-hydroxy-5-[(2S)-3- methyl-2 \{[methyl(\{[2-(propan-2-yl)-1,3-tiazole4yl]methyl $\})$ carbamoyl $]$ amino $\}$ butanamido]-1,6- diphenylhexanyl] carbamate. It is a xanthine derivative drug used in the treatment of asthma. (also known as doxophylline). It has anti tussive and bronchodilator effects, and acts as a phosphodiesterase inhibitor. Literature survey revealed that very few methods have been reported for the analysis Montelukast and doxofylline combinational dosage forms which include UV spectroscopy, Reverse Phase High performance Liquid Chromatography, Densitometric method, HPTLC methods

\section{EXPERIMENTAL}

\section{Reagents and Chemicals}

Montelukast API and doxofyllin API were obtained as gift sample from Chandra labs. Methanol, Sodium dihydrogen ortho phosphate Water, Potassium Dihydrogen ortho Phosphate, Dipotassium hydrogen ortho phosphate, Ammonium acetate, Tetra Hydro Furan, is used of HPLC grade and pur-chased

\section{Instrumentation}

Chromatographic separation was performed on a Shimadzu (LC 20 AT VP) HPLC with auto sampler and PDA Detector.variablewavelength programmable UV/VIS detector, HYPERSIL,ODS (C18 250x 4.6 ID) $5 \mu \mathrm{m}$ with $10 \mu$ l fixed loop.

\section{Chromatographic Conditions}

HYPERSIL, ODS (C18 250x4.6 ID) 5 $\mu \mathrm{m}$ were the column used for separation. Mobile phase Containing a mixture of Ammonium acetate: Methanol in $1000 \mathrm{ml}$ of water in the ratio (60:40) v/v was delivered at a flow rate of $1.0 \mathrm{ml} / \mathrm{min}$ with detection at $219 \mathrm{~nm}$. The mobile phase is filtered through a 0.45 nylon filter and sonicated for $20 \mathrm{~min}$. 


\section{Method Development}

Ammonium acetate, methanol and water in different proportions were tried and finally Ammonium acetate, methanol $=60: 40 \mathrm{v} / \mathrm{v}$ was selected appropriate mobile phase which gave good resolution, retention time and acceptable system suitability parameters.

\section{Procedure}

\section{Preparation of standard solution}

$2.5 \mathrm{mg}$ of MONTELUKAST and $100 \mathrm{mg}$ of DOXOFYLLINE was weighed in $100 \mathrm{ml}$ of volumetric flask and dissolved in $10 \mathrm{ml}$ of mobile phase and volume was made up to the mark with mobile phase. From above stock solution $2.5 \mu \mathrm{g} / \mathrm{ml}$ of MONTELUKAST and $100 \mu \mathrm{g} / \mathrm{ml}$ of DOXOFYLLINE were prepared by diluting $1 \mathrm{ml}$ to $10 \mathrm{ml}$ with mobile phase.

\section{Procedure}

Inject the samples to the RpHplc by changing the chromatographic conditions and record the chromatograms, note the conditions of proper peak elution and retention for performing valida tion parameters as per ICH guidelines

\section{Linearity}

Standard stock solutions of MONTELUKAST and DOXOFYLLINE $(\mu / \mathrm{ml})$ were prepared by dissolving $2.5 \mathrm{mg}$ of MONTELUKAST and $100 \mathrm{mg}$ of DOXOFYLLINE in $100 \mathrm{ml}$ of mobile phase. After that filtered the solution using 0.45 -micron syringe filter and sonicated for $5 \mathrm{~min}$ and diluted to $100 \mathrm{ml}$ with mobile.

\section{Procedure for Analysis of Tablets}

For Standard sample Standard stock solutions of MONTELUKAST and DOXOFYLLINE (micro gram $/ \mathrm{ml}$ ) were prepared by dissolving $2.5 \mathrm{mg}$ of MONTELUKAST and $100 \mathrm{mg}$ of DOXOFYLLINE insufficient mobile phase. After that the solution was filtered using 0.45-micron syringe filter and sonicated for $5 \mathrm{~min}$ and diluted to $100 \mathrm{ml}$ with mobile phase. Further dilutions were prepared in 5replicates of $2.5 \mu \mathrm{g} / \mathrm{ml}$ of MONTELUKAST and $100 \mu \mathrm{g} / \mathrm{ml}$ of DOXOFYLLINE were made by adding $1 \mathrm{ml}$ of stock solution to $10 \mathrm{ml}$ of mobile phase.

For Tablet sample20 tablets (each tablet contains $10 \mathrm{mg}$ of MONTELUKAST and $400 \mathrm{mg}$ of DOXOFYLLINE) were weighed and taken into a mortar and crushed to fine powder and uniformly mixed. Tablet stock solutions of MONTELUKAST and DOXOFYLLINE $(\mu \mathrm{g} / \mathrm{ml})$ were prepared by dissolving weight equivalent to $2.5 \mathrm{mg}$ of MONTELUKAST and $100 \mathrm{mg}$ of DOXOFYLLINE and dissolved in sufficient mobile phase. After that the solution was filtered using 0.45-micron syringe filter and sonicated for $5 \mathrm{~min}$ and diluted to $100 \mathrm{ml}$ with mobile phase.

\section{METHOD VALIDATION}

\section{System Suitability}

Standard solutions were prepared as per the test method and injected into the chromatographic system. The system suitability parameters like theoretical plates, resolution and asymmetric factor were evaluated.

\section{Procedure}

The standard solution was injected for five times and measured the area for all five injections in HP LC. The \%RSD for the area of five replicate injections was found to be within the specified limits.

\section{Specificity}

There is no interference of mobile phase, solvent and placebo with the analyte peak and also the peak purity of analyte peak which indicate that the method is specific for the analysis of analytes in their dosage form.

\section{Standard Sample}

Standard stock solutions of MONTELUKAST and DOXOFYLLINE (microgram/ml) were prepared by dissolving $2.5 \mathrm{mg}$ of MONTELUKAST and $100 \mathrm{mg}$ of DOXOFYLLINE dissolved in sufficient mobile phase. After that filtered the solution using 0.45-micron syringe filter and Sonicated for $5 \mathrm{~min}$ 
and dilute to $100 \mathrm{ml}$ with mobile phase. Further dilutions are prepared in 5 replicates of $2.5 \mu \mathrm{g} / \mathrm{ml}$ of MONTELUKAST and $100 \mu \mathrm{g} / \mathrm{ml}$ of DOXOFYLLINE was made by adding $1 \mathrm{ml}$ of stock solution to $10 \mathrm{ml}$ of mobile phase.

\section{Tablet Sample}

20 tablets (each tablet contains $10 \mathrm{mg}$ of MONTELUKAST and $400 \mathrm{mg}$ of DOXOFYLLINE) were weighed and taken into a mortar and crushed to fine powder and uniformly mixed. Tablet stock solutions of MONTELUKAST and DOXOFYLLINE $(\mu \mathrm{g} / \mathrm{ml})$ were prepared by dissolving weight equivalent to $2.5 \mathrm{mg}$ of MONTELUKAST and $100 \mathrm{mg}$ of DOXOFYLLINE and dissolved in sufficient mobile phase. After that filtered the solution using 0.45-micron syringe filter and Sonicated for $5 \mathrm{~min}$ and dilute to $100 \mathrm{ml}$ with mobile phase. Further dilutions are prepared in 5 replicates of 2.5 $\mu \mathrm{g} / \mathrm{ml}$ of MONTELUKAST and $100 \mu \mathrm{g} / \mathrm{ml}$ of DOXOFYLLINE was made by adding $1 \mathrm{ml}$ of stock solution to $10 \mathrm{ml}$ of mobile phase.

\section{Linearity}

linearity responses in the range of $1.5-3.5 \mathrm{mg} / \mathrm{ml}$ of DOXOFYLLINE and 60-140mg/ml of MONTE LUKAS SODIUM . Linear regression data was given

\section{Precision}

The precision of the method was demonstrated by inter day and intraday studies. In the intraday studie s, solutions of standard and sample were repeated 3times in a day and percent relative standard deviati on (\%RSD) was calculated. The intraday \%RSD of Ritonavir and Atazanavir were foundto be 0.54 an $\mathrm{d} 0.8$ respectively.In the interday variation studies, injections of standard and sample solutions were $\mathrm{m}$ ade on two days and \% RSD was calculated. The interday \% RSD for Ritonavir and Atazanavir were found to be 0.5 to 0.63 respectively. From the data obtained the developed RP-HPLC method was found to be precise.

\section{Accuracy}

Accuracy of the method was determined by Recovery studies. To the formulation (pre-analysed sample), the reference standards of the drugs were added at the level of $80 \%, 100 \%, 120 \%$. The recovery studies were carried out three times and the percentage recovery and percentage mean recovery were calculated for drug is shown in table. To check the accuracy of the method, recovery studies were carried out by addition of standard drug solution to pre-analysed sample solution at three different levels $80 \%, 100 \%, 120 \%$.

\section{Limit of Detection and Limit of Quantification}

The Limit of detection and quantification were calculated using standard deviation of the resp onse and slope of calibration curve. The LOD for this method was found to be $0.021 \mu \mathrm{g} / \mathrm{ml} \&$ area 2.61 for MONTELUKAST and $1.54 \mu \mathrm{g} / \mathrm{ml} \&$ area 104.45 for DOXOFYLLINE. The LOQ for this method was found to be $0.06 \mu \mathrm{g} / \mathrm{ml} \&$ area 7.91 for MONTELUKAST and $4.68 \mu \mathrm{g} / \mathrm{ml} \&$ area 316.51 for DOXOFYLLINE

\section{Robustness}

Robustness of the method was checked by making slight changes in chromatographic conditions like mobile phase ratio, $\mathrm{pH}$ of buffer, flow rate. It was observed that there were no marked changes in chromatograms, which demonstrated that the developed RP-HPLC method is robust.

\section{RESUlTS AND DiscuSSION}

Chromatographic separation was achieved on a Hypersil $\mathrm{C}_{18}$ column. The optimum wave length for the determination of Montelukast and Doxofylline was selected at 219nmonthe basis of Isosbestic point. Various trials were performed with different mobile phases in differentratios, Ammonium acetate: Methanol (60:40) was selected as good peak symmetry and resolution between the peaks was observed. The Retentiontime of Montelukast and Doxofylline were found to be 2.34 and 4.81 respectively. The retention times for both the drugs were considerably less compared to the retention time obtained for the drugs in the other mobile phase. 


\section{S. Marakatham et al.}

The different analytical performance parameters such as linearity, precision, accuracy, and specificity, LOD, LOQ were determined according to International Conferenceon Harmonization ICHQ2B guidelines. The calibration curve for Montelukast was obtained by plotting peak area versus the concentration over the range of $1.5-3.5 \mu \mathrm{g} / \mathrm{mL}$ and for Doxofylline over the concentration range of $60-140 \mu \mathrm{g} / \mathrm{mL}$. From linearity the correlation coefficient $\mathrm{R}^{2}$ value was found to be 0.999 for Montelukast and .998 for Doxofylline. The proposed HPLC method was also validated for system suitability, system precision and method precision. The \%RSD in the peak area of drug was found to be less than $2 \%$.The number of theoretical plates was found to be not less than2000, which indicates efficient performance of the column. The limit of detection of Montelukast \& Doxofylline $0.021 \mu \mathrm{g} / \mathrm{ml} \&$ area 2.61 and $1.54 \mu \mathrm{g} / \mathrm{ml} \&$ area 104.45 respectively. The limit of quantitation of Montelukast was found to be $0.06 \mu \mathrm{g} / \mathrm{ml} \&$ area 7.91 whereas for Doxofylline was $4.68 \mu \mathrm{g} / \mathrm{ml} \&$ area 316.51.The percentage of recovery of Montelukast and Doxofylline was found to be $99.96 \%$ and $100.85 \%$ respectively.

\section{Accuracy}

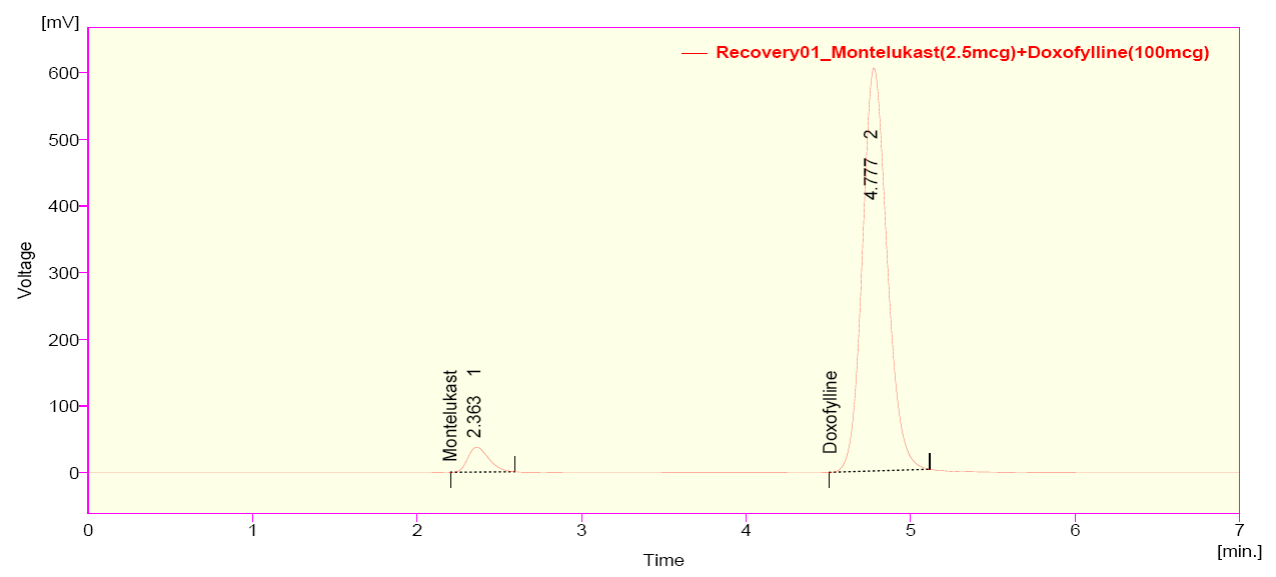

Fig 1.1. Chromatogram of $80 \%$ recovery (injection 1)

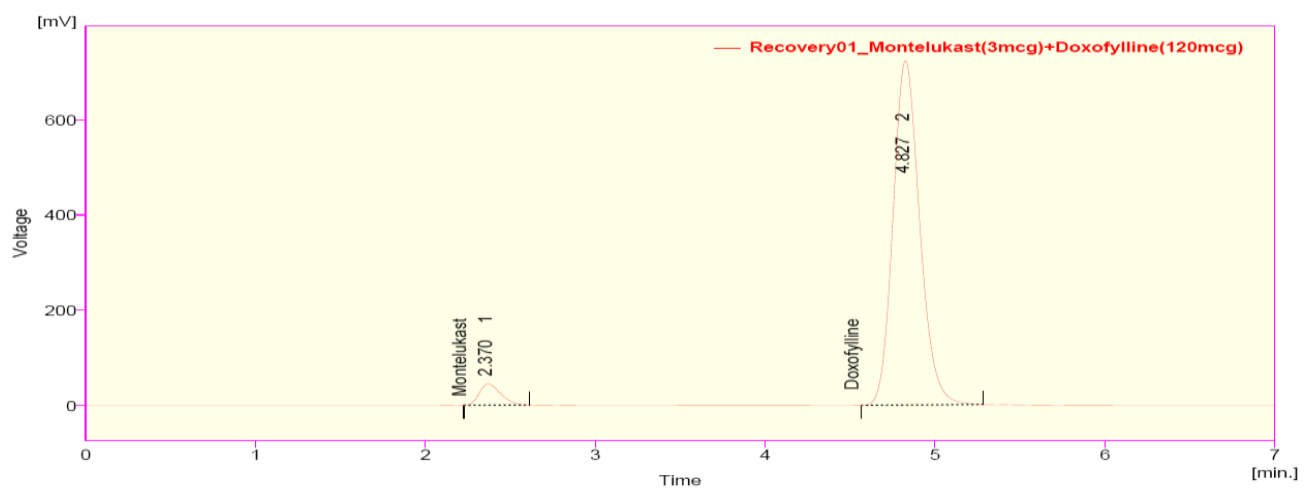

Fig 1.2. Chromatogram of $100 \%$ recovery (injection 1)

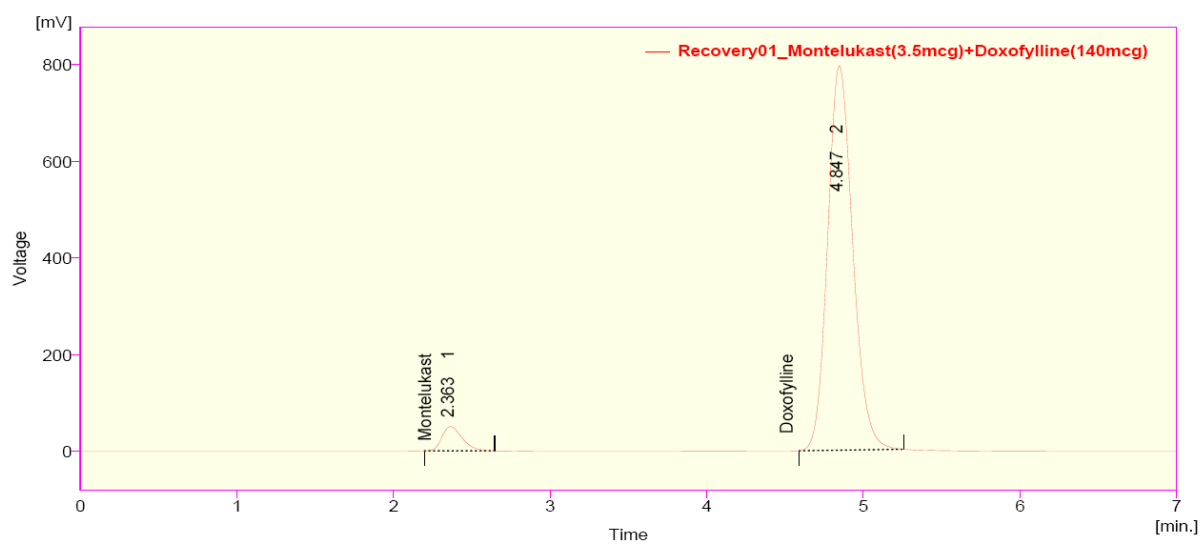

Fig 1.3. Chromatogram of $120 \%$ recovery (injection 1) 
Analytical Method Development and Validation for Simultaneous Estimation of Doxofylline and Montelukast Sodium in Bulk and Pharmaceutical Dosage Form

Table 1.1. Recovery results for MONTELUKAST MALEATE

\begin{tabular}{|c|c|c|c|c|c|c|}
\hline \multirow{2}{*}{$\begin{array}{l}\text { Recovery } \\
\text { level }\end{array}$} & \multicolumn{5}{|c|}{ Accuracy MONTELUKAST MALEATE } & \multirow{2}{*}{$\begin{array}{l}\text { Average } \\
\% \text { Recovery }\end{array}$} \\
\hline & $\begin{array}{l}\text { Amount } \\
\text { taken }(\mathrm{mcg} / \mathrm{ml})\end{array}$ & Area & $\begin{array}{l}\text { Average } \\
\text { area }\end{array}$ & $\begin{array}{l}\text { Amount } \\
\text { recovered }(\mathrm{mcg} / \mathrm{ml})\end{array}$ & \%Recovery & \\
\hline \multirow[t]{3}{*}{$80 \%$} & 2.5 & 295.482 & \multirow{3}{*}{299.503} & \multirow{3}{*}{2.46} & \multirow{3}{*}{98.50} & \multirow{9}{*}{$99.96 \%$} \\
\hline & 2.5 & 301.897 & & & & \\
\hline & 2.5 & 301.131 & & & & \\
\hline \multirow[t]{3}{*}{$100 \%$} & 3.0 & 393.495 & \multirow{3}{*}{382.759} & \multirow{3}{*}{3.02} & \multirow{3}{*}{100.52} & \\
\hline & 3.0 & 370.824 & & & & \\
\hline & 3.0 & 383.957 & & & & \\
\hline \multirow[t]{3}{*}{$120 \%$} & 3.5 & 453.643 & \multirow{3}{*}{453.048} & \multirow{3}{*}{3.54} & \multirow{3}{*}{101.01} & \\
\hline & 3.5 & 453.573 & & & & \\
\hline & 3.5 & 451.928 & & & & \\
\hline
\end{tabular}

Table 1.2. Recovery results for DOXOFYLLINE

\begin{tabular}{|c|c|c|c|c|c|c|}
\hline \multirow{2}{*}{$\begin{array}{l}\text { Recovery } \\
\text { level }\end{array}$} & \multicolumn{5}{|c|}{ Accuracy DOXOFYLLINE } & \multirow{2}{*}{$\begin{array}{l}\text { Average } \\
\text { \%Recovery }\end{array}$} \\
\hline & $\begin{array}{l}\text { Amount } \\
\text { taken }(\mathrm{mcg} / \mathrm{ml})\end{array}$ & Area & $\begin{array}{l}\text { Average } \\
\text { area }\end{array}$ & $\begin{array}{l}\text { Amount } \\
\text { recovered }(\mathrm{mcg} / \mathrm{ml})\end{array}$ & \% Recovery & \\
\hline \multirow[t]{3}{*}{$80 \%$} & 100 & 6001.49 & \multirow{3}{*}{6007.368} & \multirow{3}{*}{99.00} & \multirow{3}{*}{99.00} & \multirow{9}{*}{$100.85 \%$} \\
\hline & 100 & 6004.105 & & & & \\
\hline & 100 & 6016.51 & & & & \\
\hline \multirow[t]{3}{*}{$100 \%$} & 120 & 7701.563 & \multirow{3}{*}{7746.327} & \multirow{3}{*}{121.42} & \multirow{3}{*}{101.18} & \\
\hline & 120 & 7700.292 & & & & \\
\hline & 120 & 7837.127 & & & & \\
\hline \multirow[t]{3}{*}{$120 \%$} & 140 & 8876.873 & \multirow{3}{*}{8911.900} & \multirow{3}{*}{142.72} & \multirow{3}{*}{101.77} & \\
\hline & 140 & 8954.163 & & & & \\
\hline & 140 & 8904.665 & & & & \\
\hline
\end{tabular}

\section{Precision}

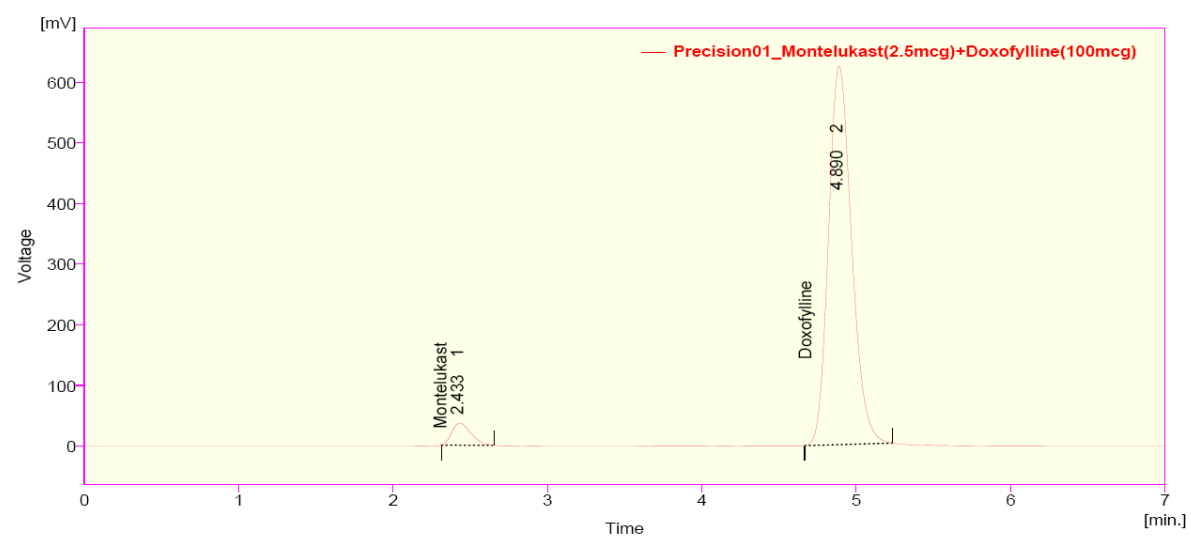

Fig 2.1. Chromatogram of precision injection 1

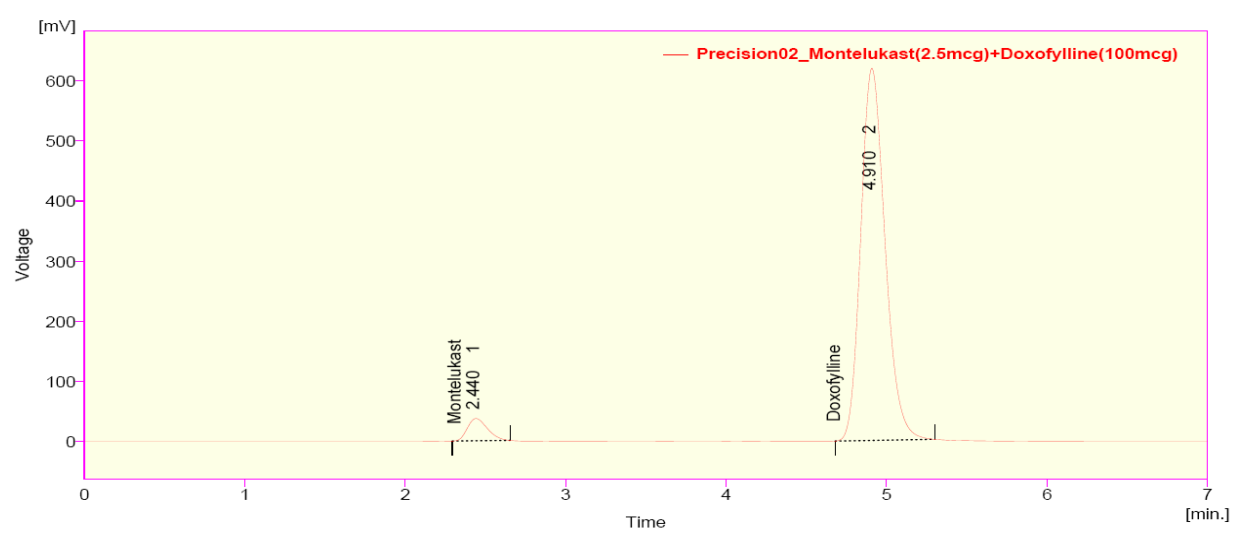

Fig 2.2. Chromatogram of precision injection 2 


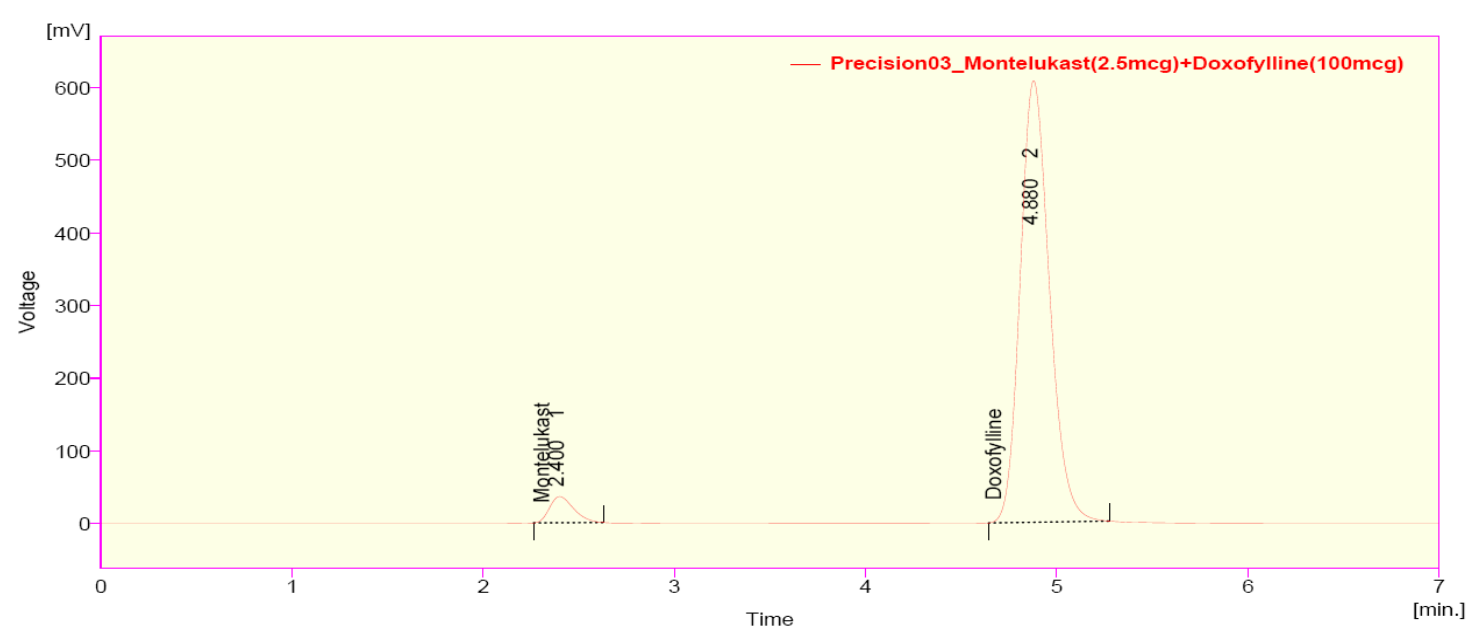

Fig 2.3. Chromatogram of precision injection 3

Table 2.1. Results for Method precision of MONTELUKAST and DOXOFYLLINE

\begin{tabular}{|l|l|l|}
\hline \multicolumn{3}{|l|}{ MONTELUKAST MALEATE } \\
\hline S.no. & Rt & Area \\
\hline 1 & 2.433 & 313.168 \\
\hline 2 & 2.440 & 321.118 \\
\hline 3 & 2.400 & 316.430 \\
\hline 4 & 2.393 & 314.869 \\
\hline 5 & 2.39 & 320.446 \\
\hline 6 & 2.353 & 320.807 \\
\hline Avg & 2.4015 & 317.806 \\
\hline St dev & 0.0317 & 3.434 \\
\hline \% RSD & 1.32 & 1.08 \\
\hline
\end{tabular}

\begin{tabular}{|l|l|l|}
\hline DOXOFYLLINE \\
\hline S.no. & Rt & Area \\
\hline 1 & 4.890 & 6496.346 \\
\hline 2 & 4.910 & 6510.812 \\
\hline 3 & 4.880 & 6472.945 \\
\hline 4 & 4.813 & 6438.985 \\
\hline 5 & 4.863 & 6457.04 \\
\hline 6 & 4.840 & 6394.355 \\
\hline Avg & 4.866 & 6461.747 \\
\hline St dev & 0.035 & 41.980 \\
\hline \% RSD & 0.72 & 0.65 \\
\hline
\end{tabular}

\section{Observation}

Test results for DOXOFYLLINE and MONTELUKAST are showing that the \%RSD of Assay results are within limits. The results were shown in table 8.2.7.

\section{Specificity}

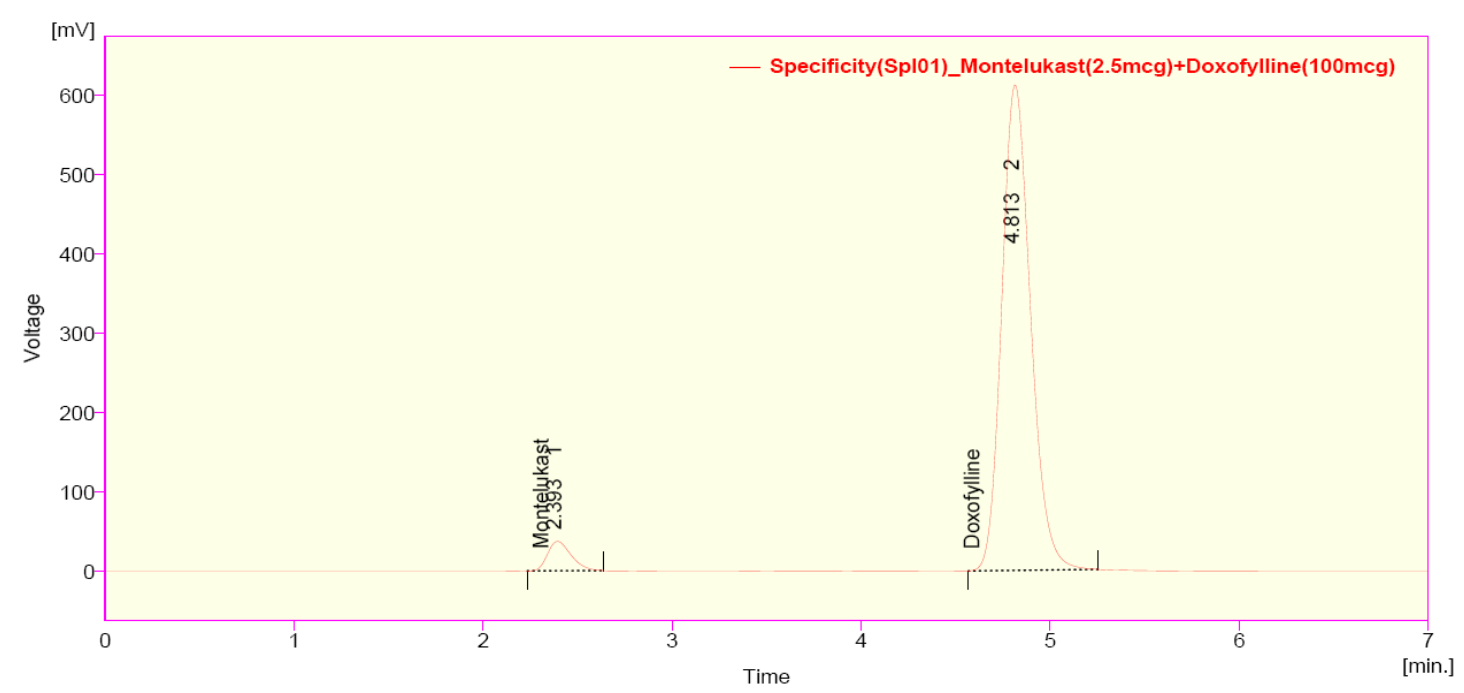

Fig 3.1. Chromatogram for specificity of MONTELUKAST and DOXOFYLLINE sample

Table 3.1. Results for Specificity of MONTELUKAST and DOXOFYLLINE

\begin{tabular}{|l|l|l|l|l|l|}
\hline NAME & Rt & AREA & Th.Plates & ASSYMETRY & RESOLUTION \\
\hline MONTELUKAST & 2.393 & 321.015 & 2619 & 1.567 & \\
\hline DOXOFYLLINE & 4.813 & 6474.853 & 4621 & 1.325 & 9.287 \\
\hline
\end{tabular}


Analytical Method Development and Validation for Simultaneous Estimation of Doxofylline and Montelukast Sodium in Bulk and Pharmaceutical Dosage Form

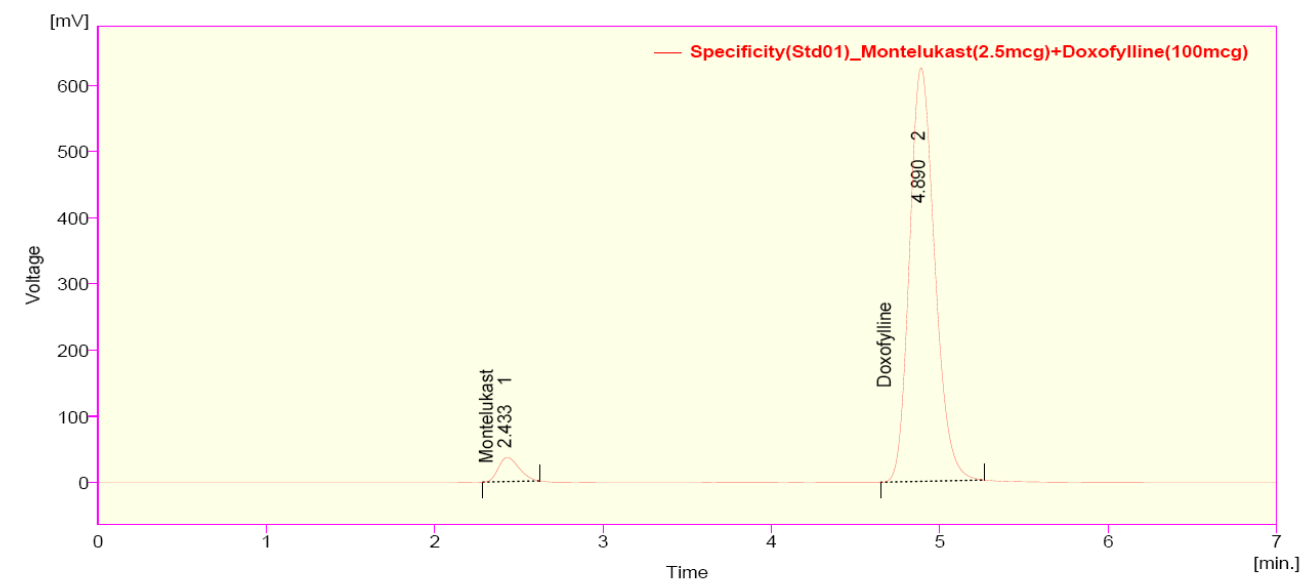

Fig 3.2. Chromatogram for Specificity of MONTELUKAST and DOXOFYLLINE standard

Table 3.2. Results for Specificity of MONTELUKAST and DOXOFYLLINE

\begin{tabular}{|l|l|l|l|l|l|}
\hline NAME & Rt & AREA & Th.Plates & ASSYMETRY & RESOLUTION \\
\hline MONTELUKAST & 2.433 & 310.503 & 2756 & 1.467 & \\
\hline DOXOFYLLINE & 4.890 & 6522.485 & 4966 & 1.300 & 9.637 \\
\hline
\end{tabular}

\section{Observation}

It is observed from the above data, diluents or excipient peaks are not interfering with the MONTELUKAST and DOXOFYLLINE peaks.

\section{Limit of Detection}
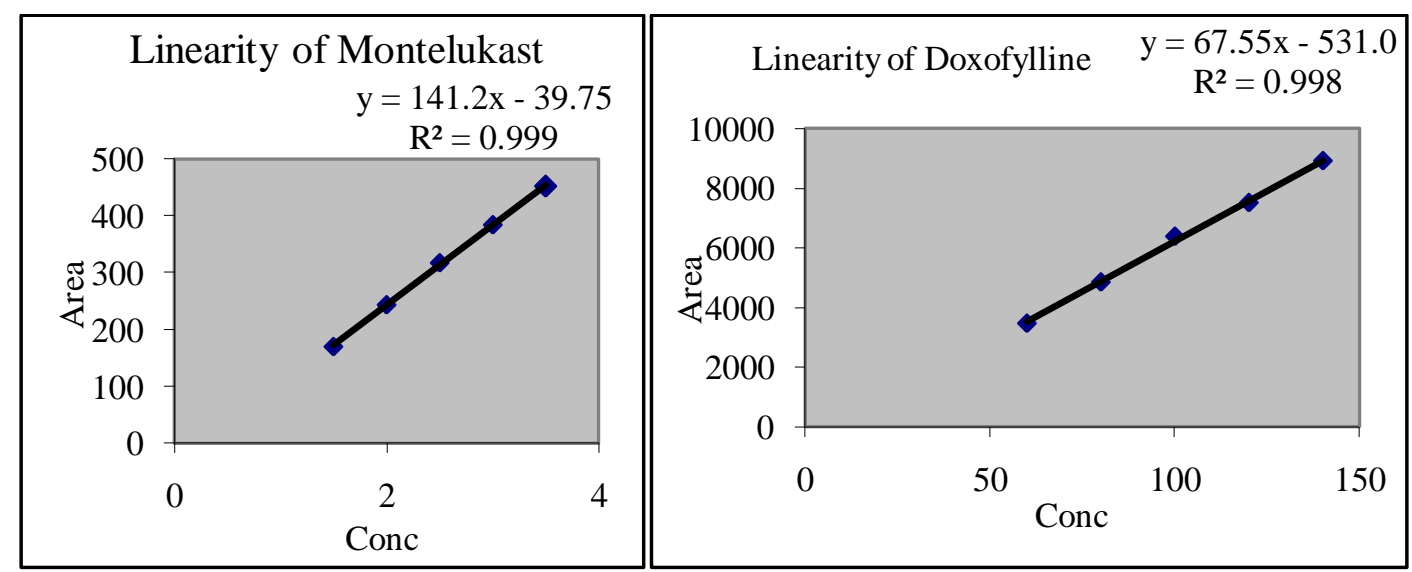

Fig 4.1. Calibration graphs of DOXOFYLLINE \& MONTELUKAST MALEATE

Table 4.1. Results for calibration graph

\begin{tabular}{|l|l|l|l|l|}
\hline & MONTELUKAST MALATE & DOXOFYLLINE \\
\hline S.No. & Concentration $\mu \mathrm{g} / \mathrm{ml}$ & Peak Area & Concentration $\mu \mathrm{g} / \mathrm{ml}$ & Peak Area \\
\hline 1 & 1.5 & 169.476 & 60 & 3475.465 \\
\hline 2 & 2 & 243.263 & 80 & 4854.281 \\
\hline 3 & 2.5 & 317.33 & 100 & 6379.981 \\
\hline 4 & 3 & 384.46 & 120 & 7506.113 \\
\hline 5 & 3.5 & 451.928 & 140 & 8904.665 \\
\hline S.D. & 0.8 & 112 & 31.62 & 2138 \\
\hline Slope & \multicolumn{3}{|l|}{} \\
\hline
\end{tabular}

\section{Observation}

The LOD for this method was found to be $0.021 \mu \mathrm{g} / \mathrm{ml} \&$ area 2.61 for MONTELUKAST and 1.54 $\mu \mathrm{g} / \mathrm{ml} \&$ area 104.45 for DOXOFYLLINE 


\section{Limit of Quantification}

$$
\mathrm{LOQ}=\frac{10 \sigma}{\mathrm{S}}
$$

Where,

$\sigma=$ the standard deviation of the response

$\mathrm{S}=$ the slope of the calibration curve

The slope $\mathrm{S}$ may be estimated from the calibration curve of the analyte.

\section{Observation}

The LOQ for this method was found to be $0.06 \mu \mathrm{g} / \mathrm{ml} \&$ area 7.91 for MONTELUKAST and 4.68 $\mu \mathrm{g} / \mathrm{ml} \&$ area 316.51 for DOXOFYLLINE

\section{Linearity and Range}

Table 6.1. Linearity Preparations

\begin{tabular}{|l|l|l|l|l|}
\hline \multirow{2}{*}{ Preparations } & $\begin{array}{l}\text { Volume from } \\
\text { standard } \\
\text { transferred in ml }\end{array}$ & $\begin{array}{l}\text { Volume made up in } \\
\text { ml } \begin{array}{l}\text { (with mobile } \\
\text { phase) }\end{array}\end{array}$ & \multicolumn{2}{l|}{ Concentration of solution $(\boldsymbol{\mu g} / \mathbf{m l})$} \\
\cline { 3 - 5 } & 10 & MONTELUKAST & DOXOFYLLINE \\
\hline Preparation 1 & 0.6 & 10 & 2 & 60 \\
\hline Preparation 2 & 0.8 & 10 & 2.5 & 80 \\
\hline Preparation 3 & 1.0 & 10 & 3 & 100 \\
\hline Preparation 4 & 1.2 & 10 & 3.5 & 120 \\
\hline Preparation 5 & 1.4 & & 140 \\
\hline
\end{tabular}

Table 6.2. Linearity of MONTELUKAST

\begin{tabular}{|l|l|l|}
\hline S.no. & Conc. $(\boldsymbol{\mu g} / \mathbf{m l})$ & Area \\
\hline 1 & 1.5 & 169.476 \\
\hline 2 & 2 & 243.263 \\
\hline 3 & 2.5 & 317.33 \\
\hline 4 & 3 & 384.46 \\
\hline 5 & 3.5 & 451.928 \\
\hline
\end{tabular}

Table 6.3. Linearity of DOXOFYLLINE

\begin{tabular}{|l|l|l|}
\hline S.no. & Conc. $(\boldsymbol{\mu g} / \mathbf{m l})$ & Area \\
\hline 1 & 60 & 3475.465 \\
\hline 2 & 80 & 4854.281 \\
\hline 3 & 100 & 6379.981 \\
\hline 4 & 120 & 7506.113 \\
\hline 5 & 140 & 8904.665 \\
\hline
\end{tabular}

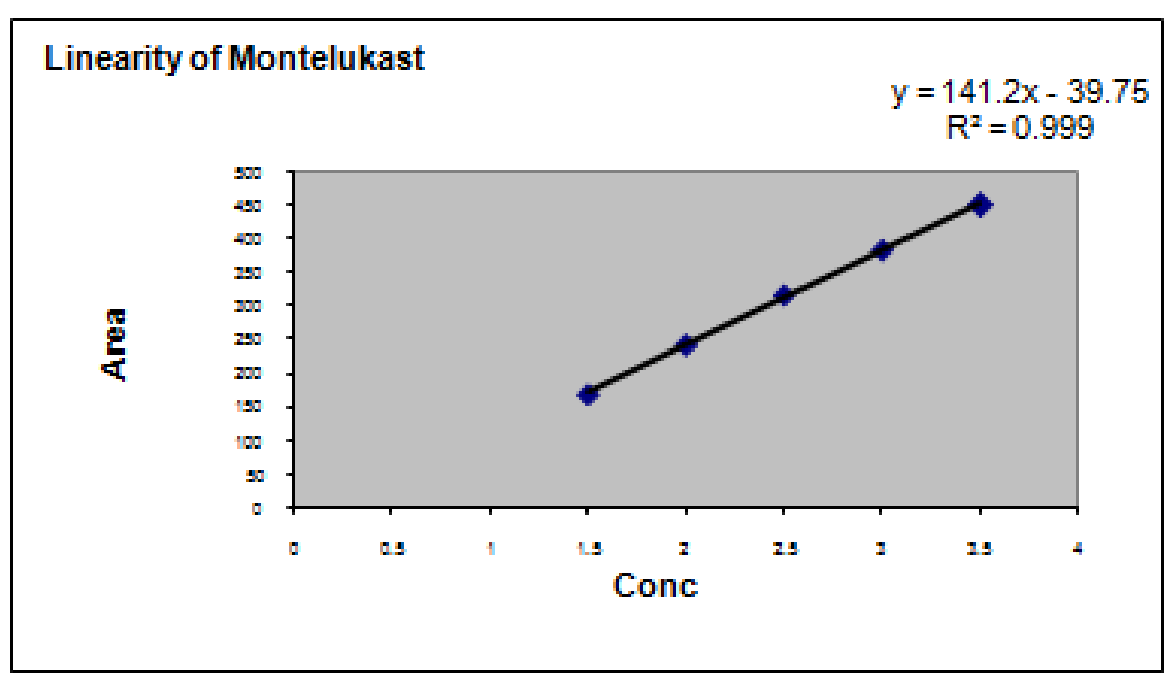

Fig 6.1. Linearity graph of MONTELUKAST 
Analytical Method Development and Validation for Simultaneous Estimation of Doxofylline and Montelukast Sodium in Bulk and Pharmaceutical Dosage Form

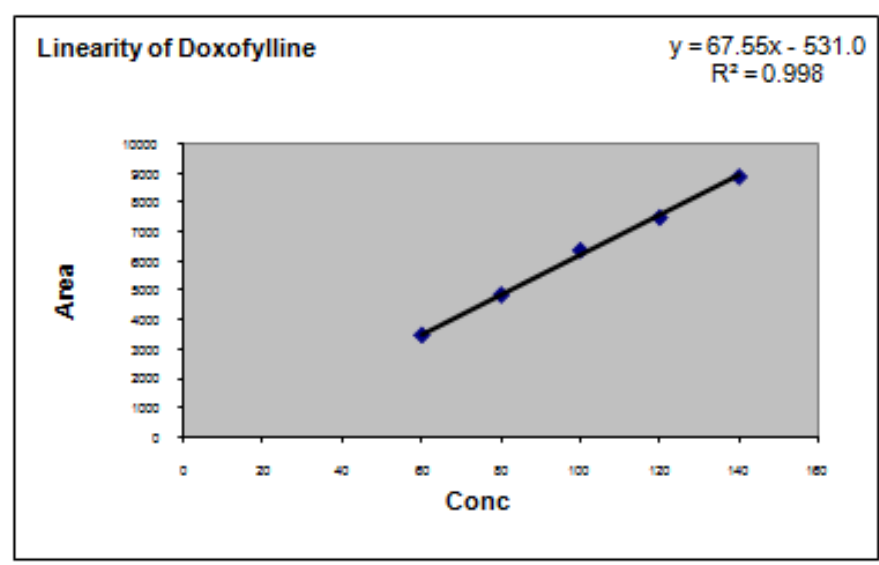

Fig 6.2. Linearity graph of DOXOFYLLINE

\section{Robustness}

Table 7.1. Result of Robustness study

\begin{tabular}{|c|c|c|c|c|}
\hline \multirow[b]{2}{*}{ Parameter } & \multicolumn{2}{|c|}{ MONTELUKAST MALEATE } & \multicolumn{2}{|l|}{ DOXOFYLLINE } \\
\hline & Retention time(min) & Tailing factor & Retention time(min) & Tailing factor \\
\hline $\begin{array}{l}\text { Flow Rate } \\
0.8 \mathrm{ml} / \mathrm{min} \\
1.0 \mathrm{ml} / \mathrm{min}\end{array}$ & $\begin{array}{l}3.953 \\
2.100\end{array}$ & $\begin{array}{l}1.567 \\
1.500\end{array}$ & $\begin{array}{l}8.010 \\
4.017\end{array}$ & $\begin{array}{l}1.306 \\
1.239\end{array}$ \\
\hline $\begin{array}{l}\text { Wavelength } \\
217 \mathrm{~nm} \\
219 \mathrm{~nm}\end{array}$ & $\begin{array}{l}2.373 \\
2.347\end{array}$ & $\begin{array}{l}1.567 \\
1.581\end{array}$ & $\begin{array}{l}4.793 \\
4.837\end{array}$ & $\begin{array}{l}1.149 \\
1.150\end{array}$ \\
\hline
\end{tabular}

\section{System suitability}

Table 8.1. Results for system suitability of MONTELUKAST

\begin{tabular}{|l|l|l|l|l|}
\hline Injection & Retention time (min) & Peak area & Theoretical plates (TP) & $\begin{array}{l}\text { Tailing factor } \\
\text { (TF) }\end{array}$ \\
\hline 1 & \multicolumn{1}{|c|}{2.431} & 312.548 & 2630 & 1.500 \\
\hline 2 & 2.401 & 312.324 & 2640 & 1.510 \\
\hline 3 & 2.441 & 314.230 & 2627 & 1.503 \\
\hline 4 & 2.403 & 317.879 & 2634 & 1.516 \\
\hline 5 & 2.394 & 318.646 & 2634 & 1.503 \\
\hline 6 & 2.391 & 318.242 & 2619 & 1.510 \\
\hline Mean & 2.3915 & 315.806 & - & - \\
\hline SD & 0.0417 & 3.644 & - & - \\
\hline$\%$ RSD & 1.021 & 0.94 & - & - \\
\hline
\end{tabular}

Table 8.2. Results for system suitability of DOXOFYLLINE

\begin{tabular}{|l|l|l|l|l|l|}
\hline Injection & Retention time (min) & Peak area & Theoretical plates & Tailing factor & Resolution \\
\hline 1 & 4.870 & 6478.985 & 4207 & 1.183 & 9.126 \\
\hline 2 & 4.860 & 6417.256 & 4270 & 1.178 & 9.142 \\
\hline 3 & 4.890 & 6498.254 & 4211 & 1.175 & 9.175 \\
\hline 4 & 4.803 & 6474.147 & 4295 & 1.172 & 9.163 \\
\hline 5 & 4.833 & 6484.256 & 4215 & 1.170 & 9.128 \\
\hline 6 & 4.820 & 6471.256 & 4219 & 1.171 & 9.176 \\
\hline Mean & 4.851 & 6425.258 & - & - & - \\
\hline SD & 0.038 & 40.210 & - & - & - \\
\hline \%RSD & 0.77 & 0.58 & - & - & - \\
\hline
\end{tabular}

\section{CONCLUSION}

From the above experimental results and parameters it was concluded that, the developed method for the simultaneous estimation of MONTELUKAST\&DOXOFYLLINE was found to be simple, precise, accurate and high resolution and shorter retention time makes this method more acceptable and cost effective and it can be effectively applied for routine analysis in research institutions, quality control 
department in meant in industries, approved testing laboratories, bio-pharmaceutical and bioequivalence studies and in clinical pharmacokinetic studies in near future.

\section{REFERENCES}

[1] The Drugs and Cosmetics Act and Rules, 1940.

[2] Methods of Analysis-http://www.pharmatutor.org/pharma-analysis

[3] Douglas, A.; Skoog, F.; James, H.; Stanley, R. C. Liquid Chromatography. In Instrumental Analysis, 9th ed.; Cengage Learning India Pvt. Ltd.: New Delhi, 2007; 893 - 934.

[4] Skoog; Holler; Crouch; Liquid Chromatography. In Instrumental Analysis, Cengage Learning India.: New Delhi. 2011; 893.

[5] Chatwal, R. G.; Anand, K. S. High Performance Liquid Chromatography. In Instrumental Methods Of Chemical Analysis, $5^{\text {th }}$ ed.; Himalaya Publishers.: Mumbai, 2010; 2.570 - 2.629.

[6] Sharma, B. K. High Performance Liquid Chromatography. In Instrumental Methods Of Chemical Analysis, 24 ${ }^{\text {th }}$ ed.; Goel Publishers.: Meerut, 2005; 295 - 300.

[7] Alfonso, R. G.; Ara, H. D. M.; Glen, R. H.; Thomas, M.; Nicholas, G. P.; Roger, L.S.; Steve, H. W. Chromatography. In Remington: The Science and Practice of Pharmacy, $20^{\text {th }}$ ed.; Lippincott Williams \& Wilkins: Philadelphia, 2000; 587

[8] Adsorption Chromatography- http://www.separationprocesses.com/Adsorption/AD_Chp05a.htm

[9] Adsorption Chromatography- http://cemca.org/andcollege/andcwebsite/subject01/CHEtext.pdf

[10] Types of Chromatography- http://www.separationprocesses.com/Adsorption/AD_Chp05a.htm

[11] Partition Chromatography - http://media.rsc.org/ Modern\%20chemical\% 20techniques/ MCT5\% 20Chromatography.pdf

[12] Ion Exchange Chromatography - http://www.gelifesciences.com/ webapp/wcs/stores/servlet/ catalog/en/GELifeSciences-IN/products/ion-exchange-chromatography-iex/

[13] Ion Exchange Chromatography-http://wolfson.huji.ac.il/purification/PDF/IonExchange/AMERSHAM_iIEXandChromatofocManual.pdf

[14] Size exclusion chromatography-http://www.rpi.edu/dept/chemeng/BiotechEnviron/CHROM O/be_types.htm

[15] Chiral phase chromatography-http://scholar.lib.vt.edu/ theses/ available/ etd32298223814/ unrestricted/ch_02.pdf

[16] Types of elution- http://chemwiki.ucdavis.edu/@api/deki/pages/402/pdf

[17] Types of elution-http://hplc.chem.shu.edu/NEW/HPLC_Book/Rev.-Phase/rp_grad.htmL

[18] Types of HPLC- http://www.chem.agilent.com/Library/primers/Public/59896639EN.pdf

[19] Diagram of HPLC- http://hiq.lindegas.com/international/web/lg/spg/like35lgspg.nsf/docbya lias/image_hplc

[20] Solvent Delivery System - http://www.monzirpal.net/Instrumental\%20Analysis/Lectures/Lec tures\%2021-/L39.pdf

[21] Injection valves - http://www.dolomitemicrofluidics.com/webshop/flowaccessoriesinjectionvalves-c-17_18/sample-injection-valve-p-783

[22] Injection valves -http://weather.nmsu.edu/Teaching_Material/SOIL698/Student_Material/Hpl chp1090/Hplcinj.Html

[23] Flow path of a Manual Injector - http://polymer.ustc.edu.cn/xwxx_20/ xw/201109/P02011090 6263097048536.pdf

[24] Braithwaite, A.; Smith, F. J. Liquid Phase Chromatography on Columns. In Chromatographic methods, $5^{\text {th }}$ ed.; Kluwer Academic Publishers: Netherlands, 1999; 129.

[25] Columns - International pharmacopeia, $4^{\text {th }}$ edition - http://apps.who.int/phint/en/p/docf/

[26] Detectors - http://lipidlibrary.aocs.org/ topics/detect92/file.pdf

[27] Detectors - http://www.shodex.net/index.php?seitenid=1\&applic $=1485$

[28] Method development - http://www.pharmainfo.net/ reviews/ introduction analytical method developmentpharmacutical-formulations 
[29] Manoj, K. S.; Pramod, K. S.; Sambhu, C. M.; Preet, K. K.; Nitin, K.; Rupesh, D. A perspective review on method development and validation by HPLC. International Journal of Pharmaceutical Sciences.2011, 4, 1387-1413.

[30] International Conference on Harmonization,"Q2A: Text on Validation of Analytical Procedures," Federal Register. 1995, 60, 11260-11262.

[31] International Conference on Harmonization,"Q2B: Validation of Analytical Procedures: Methodology; Availability," Federal Register. 1997, 62, 27463-27467.

[32] Michael Swartz, E.; Ira Krull, S, Analytical Method development. In Analytical Method Development and Validation, $1^{\text {st }}$ ed.; Marcel Dekker, Inc: New York, 2009; 17-80.

[33] Particle Sciences Drug Development Services. Analytic Method Development and Validation. Technical Brief. 2009, 5, 1-2.

[34] Ghulam, A. S. PLC Method Development and Validation for Pharmaceutical Analysis. Pharmaceutical Technology Europe. 2004, 7, 55 -63.

[35] Radhika, R.; Alfred, D. G. Guidance for Industry- Analytical Procedures and Methods Validation. Federal Register, 2000, 2396, 1-32.

[36] Effect of flow rate - http://www.ionsource.com/tutorial/chromatography/rphplc.htm

[37] Effect of flow rate - http://www.ionsource.com/Card/linvelocity/linvol.htm

[38] Brian, L. H.; Thomas, E. B. The Influence of Column Temperature on HPLC Chiral Separation on Macro cyclic Glycopeptide CSPs. Advanced Separation Technologies Inc. (Astec). New Jersey, USA.

[39] Effect of temperature - http://www.pharmtech.com/pharmtech/Analytical/UsingHighTemperature HPLC--for-ImprovedAnalysis/ArticleStandard/Article/detail/97082

[40] Effect of pH- http://www.laserchrom.co.uk/LaserchromHPLC-pHBufferGuide.htm

[41] Effect of $\mathrm{pH}$ - Technical tips-selecting buffer ph in reverse phase HPLC

[42] Effect of pH- http://www.sigmaaldrich.com/ content/ dam/ sigmaaldrich/ docs/ Fluka/ General_InformatIon/analytixnotes_lpc_lowres.pdf

[43] Effect of ion-pair reagent- http://www.standardbase.com/tech/HPLC\%20validation\%20PE.pdf

[44] Peak shapes - http://www.chem.agilent.com/Library/eseminars/Public/secrets\%20of\%20good $\% 20$ peak\%20shape\%20in\%20hplc.pdf

[45] Rajesh, K. P. Overview of Pharmaceutical Validation and Process Controls In Drug Development. Der Pharmacia Sinica. 2010, 1, 11 - 19.

[46] Jay, B.; Kevin, J.; Pierre, B. Understanding and Implementing Efficient Analytical Methods Development and Validation. Pharmaceutical Technology Analytical Chemistry \& Testing. 2003, 5, 6 - 13.

[47] Ludwig, H. Validation of Analytical Methods. Agilent technologies. 2007, 1- 65.

[48] MONTELUKASTdrug profile - http://www.drugbank.ca/drugs/DB00381

[49] DOXOFYLLINEdrug profile http://www.drugbank.ca/drugs/DB00678

[50] GadapaNirupa, A. Siva Kumar: Novel LC Method Development and Validation for Simultaneous Determination of Montelukast and Doxofylline in Bulk and Pharmaceutical Dosage Forms. Journal of ChemistryVolume 2013 (2013), Article ID 402723, 7 pages

[51] Thiruvengadam, Ethiraj; Ramadoss, Revathi; Vellaichamy, Ganesan: Development And Validation Of Liquid Chromatography And Spectroscopic Methods For The Analysis Of Doxofylline In Pharmaceutical Dosage Forms Source: Indonesian Journal of Pharmacy/Majalah Farmasi Indonesia;2013, Vol. 24 Issue 2, p14, March 2013

[52] Atkuru Veera Venkata Naga Krishna Sunil, Settaluri Vijaya Saradhi et.al: Development and Validation of UV Spectrophotometric Methods for Estimation of Montelukast Sodium in Bulk and Pharmaceutical Formulation. Journal of Chemistry Volume 12 2012 , ArticleID 402723, 7 pages 
[53] C Parthiban, V Prathyusha, P Jeevani, B Sowmya, M Divya Swetha, V Pallavi: Method Development And Validation For The Determination Of Monteleukast In Tablet Dosage Form By Rp-Hplc Method Inventi Rapid: Pharm Analysis \& Quality Assurance publication date: 2012/9/18

[54] Giriraj P and Shajan A: Simultaneous Estimation And Method Validation Of Montelukast Sodium And Doxofylline In Solid Dosage Form By Rp-Hplc International Journal of Chemical and Pharmaceutical Sciences2011, April., Vol.2 (1)

[55] Revathi, Ethiraj, Sarvanan: High performance liquid chromatographic method development for simultaneous analysis of doxofylline and montelukast sodium in a combined formPharm Methods. 2011 Oct-Dec; 2(4): 223-228. doi: 10.4103/2229-4708.93390

[56] Akhilesh Gupta, Swati Rawat, Mayuri Gandhi and Jaydeep Singh Yadav: Method Development And Acid Degradation Study Of Doxofylline By Rphplc And Lc-Ms/Ms Asian J. Pharm. Ana. 2011; Vol. 1: Issue 1, Pg 10-13 [AJPAna.]

[57] J.V. Shanmukha Kumar, D. Ramachandran, K. Sushma And S. Vijaya Saradhi: Visible Spectrophotometric Methods For Estimation Of Montelukast Sodium In Bulk Dosage Forms And Formulation Oriental Journal of Chemistry Vol. 26(1), 293-296 (2010)

[58] NajmulHasan, Farhan Ahmed Siddiqui, NawabSherAfridi, MathurotChaiharn, SaulehaKhan,and Mohammed Abrar: A New Acetonitrile-Free, Cost-Effective, Simple And Validated Rp-Hplc Method For Determination Of Montelukast Sodium In Bulk, Tablets And Liquid Dosage Forms Oriental Journal of Chemistry Vol. 26(1), 293-296 (2010)

[59] K. Naga Raju, T. GopalaSwamy and A. LakshmanaRao: Development And Validation Of RpHplc Method For The Determination Of Montelukast Sodium In Bulk And In Pharmaceutical FormulationJournal of Analytical Chemistry; March 2010, Volume 65, Issue 3, pp 293-297

[60] R.M. Singh, P. K. Saini, S. C. Mathur, G. N. Singh, and B. Lal: Development And Validation Of A Rp-Hplc Method For Estimation Of Montelukast Sodium In Bulk And In Tablet Dosage FormIndian J Pharm Sci. 2010 Mar-Apr; 72(2): 235-237.

[61] Joshi, H. R.; Patel, A. H.; Captain, A. D.: Spectrophotometric And Reversed-Phase HighPerformance Liquid Chromatographic Method For The Determination Of Doxophylline In Pharmaceutical Formulations, Journal of Young Pharmacists;2010, Vol. 2 Issue 3, p289

[62] Ashu Mittal, ShikhaParmar: Development And Validation Of Rapid Hplc Method For Determination Of Doxofylline In Bulk Drug And Pharmaceutical Dosage Forms Journal of Analytical Chemistry; March 2010, Volume 65, Issue 3, pp 293-297 